\title{
Lipid and lipid carbon stable isotope composition of the hydrothermal vent shrimp Mirocaris fortunata: evidence for nutritional dependence on photosynthetically fixed carbon
}

\author{
David W. Pond ${ }^{1,2}{ }^{*}$, Michel Segonzac ${ }^{3}$, Michael V. Bell $^{1}$, David R. Dixon ${ }^{2}$, \\ Anthony E. Fallick ${ }^{4}$, John R. Sargent ${ }^{1}$ \\ ${ }^{1}$ NERC Unit of Aquatic Biochemistry, Department of Biological and Molecular Sciences, University of Stirling, \\ Stirling FK9 4LA, United Kingdom \\ ${ }^{2}$ Plymouth Marine Laboratory, Prospect Place, Plymouth PL1 3DH, United Kingdom \\ ${ }^{3}$ IFREMER, BP 70, F-29280 Plouzané, Brest, France \\ ${ }^{4}$ Isotope Geosciences Unit, SURRC, East Kilbride, Glasgow G75 0QF, United Kingdom
}

\begin{abstract}
Mirocaris fortunata were sampled from the Lucky Strike hydrothermal vent area (Eiffel Tower site) on the mid-Atlantic ridge during the French DIVA 2 cruise (June 1994). Small adults (17 to $22 \mathrm{~mm}$ total length), although morphologically identical, could be divided into 2 categories on the basis of pigmentation, lipid composition and ${ }^{13} \mathrm{C} /{ }^{12} \mathrm{C}$ stable isotope ratios of fatty acids. Highly pigmented small adults (8.6 to $9.2 \mu \mathrm{g}$ carotenoid shrimp ${ }^{-1}$ ) contained higher levels of total lipid than similar-sized individuals containing lower levels of pigment $\left(0.9\right.$ to $2.9 \mu \mathrm{g}$ carotenoid shrimp $\left.{ }^{-1}\right)$. Lipid class analysis indicated that wax esters comprised $62.5 \%$ of total lipid in the former group. These pigmented shrimp also contained high proportions of polyunsaturated fatty acids (PUFA), particularly the phototrophic microplanktonic markers $20: 5(\mathrm{n}-3)$ and $22: 6(\mathrm{n}-3)$ (14.0 and $33.5 \%$ respectively). By contrast small adults $(22 \mathrm{~mm})$ and adult shrimp (25 to $26 \mathrm{~mm})$ with low levels of carotenoid pigmentation contained lower amounts of total lipid, little or no wax ester and low levels of $20: 5(n-3)$ and 22:6(n-3), but did contain 16:2(n-4) and $18: 2(n-4)$ and the non-methylene interrupted dienes $20: 2 \Delta 5,13$ and $22: 2 \Delta 7,15$. GC-IRMS analysis of all fatty acids and fatty alcohols in the pigmented small adults indicated $\delta^{13} \mathrm{C}$ values of -18.2 to $-27.7 \%$, which is consistent with a photosynthetic carbon source for these compounds. The ${ }^{13} \mathrm{C} /{ }^{12} \mathrm{C}$ isotope composition of fatty acids from low-pigmented small adults and adults was more variable $(-12.5$ to $-33.1 \%$ ) and suggests a bimodal distribution which may be attributable to differing nutritional sources or the physiological/reproductive status of these shrimp. Samples of eggs, which are carried by the female on the pleopods, represented approximately $57 \%$ of total somatic lipid which indicates a substantial reproductive investment by this species. The egg lipids comprised high proportions of triacylglycerols (64.4 to $78.0 \%$ of total lipid) whilst the fatty acid composition was dominated by the monounsaturated fatty acids $16: 1(n-7), 18: 1(n-7)$ and $18: 1(n-9)$, which accounted for 65.7 to $73.5 \%$ of total fatty acids. By contrast, PUFA were relatively minor components of egg lipids, particularly $20: 5(n-3)$ and $22: 6(n-3)$, which accounted for only 1.1 and $2.9 \%$ of total egg fatty acids respectively. This indicates that the reproductive investment by this species is supported mainly by material derived from bacterial chemosynthesis. The potential for $M$. fortunata hedge betting by producing larvae which either metamorphose at the vent site or adopt a bathypelagic lifestyle and delay metamorphosis to facilitate more widespread dispersal is discussed.
\end{abstract}

KEY WORDS: Mirocaris fortunata Lipid Stable isotope $\cdot$ Hedge betting

\section{INTRODUCTION}

Caridean shrimp of the family Alvinocarididae are common components of the megafauna on the mid-
Atlantic ridge (MAR) hydrothermal vent sites and a number of species have been described (Williams \& Rona 1986, Segonzac et al. 1993, Van Dover 1995, Vereshchaka 1996). Although all these shrimp commu- 
nities are to some extent reliant on chemolithotrophically fixed carbon, there are some species-specific differences. At one extreme, Rimicaris exoculata relies exclusively on a bacterial dietary source (Van Dover et al. 1988, Gebruk et al. 1993, Segonzac et al. 1993) whilst, at the other, Alvinocaris markensis adopts a more opportunistic, scavenging mode of nutrition (Segonzac et al. 1993, Pond et al. 1997a). The quantitative contribution and significance of photosynthetically derived material for the nutrition of the various species of vent shrimp is a major, unresolved scientific issue.

The natural abundance of ${ }^{13} \mathrm{C}$, measured as the ${ }^{13} \mathrm{C} /{ }^{12} \mathrm{C}$ isotope ratio, can be a powerful tracer to identify carbon flow and trophic interactions within hydrothermal food webs (Fisher et al. 1990). Pond et al. (1997a) found that the ${ }^{13} \mathrm{C} /{ }^{12} \mathrm{C}$ isotopic signatures of the fatty acids $20: 4(n-6), 20: 5(n-3)$, and $22: 6(n-3)$ in Rimicaris exoculata were approximately $-17 \%$, which is typical of material synthesised within the photic zone. Similarly, a study of the ${ }^{13} \mathrm{C} /{ }^{12} \mathrm{C}$ isotopic composition of sterols in hydrothermal vent organisms from the East Pacific Rise has also suggested a nutritional input of photic material to this vent ecosystem (Rieley et al. 1995). However, the ${ }^{13} \mathrm{C} /{ }^{12} \mathrm{C}$ isotopic composition of fatty acids thought to be derived from thiotrophic bacteria, such as 16:2(n-4) and 18:2(n-4), were $-11 \%$, which is consistent with these compounds being synthesised within the vent ecosystem (Pond et al. 1997a).

The caridean shrimp Mirocaris fortunata was first collected from the Lucky Strike hydrothermal vent area (MAR) and subsequently described and assigned to the genus Chorocaris by Martin \& Christiansen (1995). However, more recently it has been proposed that this species should be assigned to a new family called Mirocaris and renamed Mirocaris fortunata (Vereshchaka 1997). M. fortunata is characterised by an acute conical prominence on the lower angle of the orbit, a stout cheliped, a long chela on the second pereiopod and small size (20 to $26 \mathrm{~mm}$ ) at maturity (Martin \& Christiansen 1995). The distribution of this species is patchy, but tends to be associated with warm water and sulphide discharges where up to 20 to 30 shrimps $\mathrm{m}^{-2}$ have been observed among colonies of mussel (Bathymodiolus sp.; Van Dover 1995). A notable feature of the $M$. fortunata samples collected to date is a high proportion of gravid females (Van Dover 1995) and this contrasts to other Caridean shrimp species found at hydrothermal vents, for which few gravid females have been observed (Segonzac unpubl., P. Tyler pers. comm.).

Analysis of lipid and lipid stable isotope composition of hydrothermal vent shrimp has previously provided valuable insights into their sources of nutrition, trophic ecology and life-history strategy (Pond et al. 1997a, b).
In the current study we extend this approach to the different sexes and maturity stages of Mirocaris fortunata, a species for which little information has previously been published.

\section{METHODS}

Station location and sample collection. Mirocaris fortunata were collected during the French DIVA 2 cruise (dive PL 08) on 10 June 1994 to the Eiffel Tower site, at the Lucky Strike hydrothermal vent field $\left(37^{\circ} 17^{\prime} \mathrm{N}, 32^{\circ} 16^{\prime} \mathrm{W}\right)$. A full description of the site is given in Klinkhammer et al. (1995) and Van Dover et al. (1996). The shrimp were sampled by the IFREMER submersible, 'Nautile', from areas extensively colonised by mussels (Bathymodiolus sp.). All shrimp samples were frozen at $-70^{\circ} \mathrm{C}$ shortly after collection. Species identification was confirmed in the laboratory under low power microscopy and the total length (tail to rostrum) of each shrimp noted. Although all shrimp were adults, total length varied from 17 to $26 \mathrm{~mm}$ and individuals were therefore characterised as either small adult or adult (Table 1). Furthermore, samples of small adult shrimp, although morphologically identical, could easily be divided into 2 categories of high and low red/orange coloured pigmentation. Eggs, which contained no visible eyed ova and were attached to the female's pleopods, were carefully removed using tweezers and immediately placed in chloroform:methanol $(2: 1 \mathrm{v} / \mathrm{v})$ at $-70^{\circ} \mathrm{C}$.

Lipid analyses. Whole shrimp and egg samples were homogenised in chloroform:methanol 2:1 (v/v) before filtering through a prewashed (chloroform:methanol $2: 1 \mathrm{v} / \mathrm{v})$ Whatman No. 1 paper filter. Total lipid was then extracted following the method of Folch et al. (1957) and dried under nitrogen. Aliquots of $10 \mu \mathrm{g}$ of total lipid was separated into individual lipid classes by high performance thin layer chromatography (HPTLC) using a hexane:diethyl ether:acetic acid (90:10:1 v/v/v) solvent system. Lipid classes were visualised by spraying the plates with $8 \%(\mathrm{v} / \mathrm{v})$ phosphoric acid containing $3 \%(w / v)$ copper acetate, followed by charring at $160^{\circ} \mathrm{C}$ for $15 \mathrm{~min}$. The contribution of the various lipid classes to total lipid was determined using scanning densitometry (Olsen \& Henderson 1989).

Remaining aliquots of total lipid were transmethylated in methanol containing $1.5 \%$ (v/v) sulphuric acid for $16 \mathrm{~h}$ at $50^{\circ} \mathrm{C}$ (Christie 1982) and the fatty acid methyl esters purified by thin layer chromatography (TLC). Free fatty alcohols were recovered separately from the TLC plates, and their acetate derivatives prepared following Farquhar (1962). Component fatty acid methyl esters and fatty alcohol acetates were identified by chromatography on a Canberra 436 GC 
fitted with a BP20 fused silica capillary column (50 $\mathrm{m} \times$ $0.32 \mathrm{~mm}$ i.d. (inner diameter); SGE) using hydrogen as a carrier gas (Henderson et al. 1994). Peaks were identified by reference to samples of known composition and by gas chromatography-mass spectrometry (GC-MS) using a Fisons MD 800 fitted with a DB-5MS column (15 $\mathrm{m} \times 0.25 \mathrm{~mm}$ i.d.; J \& W Scientific) using helium as a carrier gas. Fatty acids were characterised by GC-MS after producing dimethyl disulphide adducts of monounsaturated fatty acids (Nichols et al. 1986) and diethylamide derivatives of polyunsaturated fatty acids (Nilsson \& Liljenberg 1991).

${ }^{13} \mathrm{C} /{ }^{12} \mathrm{C}$ analyses. Carbon stable isotope ratios $\left({ }^{13} \mathrm{C} /\right.$ ${ }^{12} \mathrm{C}$ ) were measured by gas chromatography-isotope ratio mass spectrometry (GC-IRMS) using a VG Isochrom II instrument whose performance has been described by Eakin et al. (1992). A fused silica capillary column (SGE: BP20; $50 \mathrm{~m} \times 0.32 \mathrm{~mm}$ i.d.) was used with helium as the carrier gas and a splitless injection mode was employed. The temperature program was: $50^{\circ} \mathrm{C}(0.1 \mathrm{~min})$ rising to $190^{\circ} \mathrm{C}$ with a $40^{\circ} \mathrm{C}$ $\mathrm{min}^{-1}$ gradient, then rising to $230^{\circ} \mathrm{C}(50 \mathrm{~min})$ with a $2.5^{\circ} \mathrm{C} \mathrm{min}^{-1}$ gradient. The fatty acid samples were injected in duplicate and compared with a reference $\mathrm{CO}_{2}$ source which was calibrated for $\delta^{13} \mathrm{C}$ (\% PDB) by conventional dual-inlet mass spectrometry. Replicate analyses gave a precision of $\pm 0.5 \%$. The $\delta^{13} \mathrm{C}$ composition of the derivatization reagents was determined as $-41.8 \%$ and $-27.0 \%$ for methanol and acetic anhydride respectively by the quartz closed tube combustion technique of Sofer (1980). For fatty acids the contribution of the derivatized carbon was calculated by rearranging the equation of Abrajano et al. (1994) assuming there is no isotopic fractionation during derivatization:

$$
\delta^{13} \mathrm{C}_{\mathrm{FA}}=\frac{\delta^{13} \mathrm{C}_{\mathrm{FAME}}-(1-x) \delta^{13} \mathrm{C}_{\mathrm{CH}_{3} \mathrm{OH}}}{X}
$$

where: $\delta^{13} \mathrm{C}_{\mathrm{FA}}$ is the isotopic composition of the free fatty acid, $\delta^{13} \mathrm{C}_{\text {FAME }}$ is the isotopic composition of the fatty acid methyl ester, $x$ is the fractional carbon contribution of the free fatty acid to the ester and $\delta^{13} \mathrm{C}_{\mathrm{CH}_{3} \mathrm{OH}}$ is the isotopic composition of the methanol derivatization reagent.

To determine if there was a significant kinetic isotope effect during acetylation, i.e. the addition of 2 carbons to the fatty alcohols, we derivatized a 19:0 fatty alcohol standard (Rieley 1994). The $\delta^{13} \mathrm{C}$ values of the 19:0 free fatty alcohol and fatty alcohol acetate derivatives were $-30.6 \%(-30.4$ to $-30.7 \%$ o $)$ and $-31.6 \%(-31.5$ to $-32.0 \%$ ol respectively. Given that the $\delta^{13} \mathrm{C}$ value for the acetic anhydride was $-27.0 \%$, we would predict a derivatized value of $-30.3 \%$. As the measured value was isotopically lighter than predicted, i.e. $-31.6 \%$, this indicates a kinetic isotope effect during acetylation. $\delta^{13} \mathrm{C}$ values of fatty alcohol acetates determined by GC-IRMS were corrected accordingly.

Total carotenoid pigment analysis. Samples of total lipid containing the carotenoid pigments were dissolved in $1 \mathrm{ml}$ hexane with $10 \mu \mathrm{l}$ chloroform and total carotenoids quantified spectrophotometrically at $470 \mathrm{~nm}$.

\section{RESULTS}

As no dry or wet weight determinations were made of the shrimp samples, the total carotenoid and lipid data cannot be expressed on a per unit weight basis. However, even by considering total carotenoid and lipid content per shrimp, clear trends emerge. The

Table 1 Mirocaris fortunata. Lipid class composition (\%) of various life stages. pigm.. pigmentation; tr: trace quantities

\begin{tabular}{|c|c|c|c|c|c|c|c|c|c|c|}
\hline & $\begin{array}{l}\text { Small adult } \\
\text { low pigm. } \\
\qquad\left(a_{1}\right)\end{array}$ & $\begin{array}{l}\text { Small adult } \\
\text { low pigm. } \\
\qquad\left(b_{1}\right)\end{array}$ & $\begin{array}{l}\text { Small adult } \\
\text { low pigm. } \\
\left(c_{1}\right)\end{array}$ & $\begin{array}{l}\text { Small adult } \\
\text { low pigm. } \\
\left(\mathrm{d}_{1}\right)\end{array}$ & $\begin{array}{l}\text { Small adult } \\
\text { high pigm. } \\
\qquad\left(\mathrm{a}_{2}\right)\end{array}$ & $\begin{array}{l}\text { Small adult } \\
\text { high pigm. } \\
\qquad\left(b_{2}\right)\end{array}$ & $\begin{array}{l}\text { Adult } \\
\left(\mathrm{a}_{3}\right)\end{array}$ & $\begin{array}{c}\text { Adult } \\
\left(\mathrm{b}_{3}\right)\end{array}$ & $\begin{array}{c}\text { Female w } \\
\text { Female }\end{array}$ & $\begin{array}{c}\text { th eggs } \\
\text { Eggs }\end{array}$ \\
\hline Total length (mm) & 18 & 22 & 22 & 22 & 17 & 19 & 25 & 26 & 25 & \\
\hline \multicolumn{11}{|l|}{ Lipid class } \\
\hline Polar lipid & 20.7 & 25.1 & 23.3 & 32.5 & 9.9 & 11.3 & 16.9 & 30.4 & 25.2 & 14.1 \\
\hline Diacylglycerols & $\operatorname{tr}$ & $\operatorname{tr}$ & $\operatorname{tr}$ & 0 & 0 & 0 & 0 & 0 & 1.9 & 1.7 \\
\hline Sterols & 12.4 & 12.6 & 9.9 & 23.1 & 5.1 & 6.4 & 9.8 & 20.4 & 14.6 & 6.1 \\
\hline Free fatty alcohol & $\operatorname{tr}$ & tr & 1.2 & 2.6 & 6.1 & 6.3 & 2.1 & 0 & 2.6 & 1.7 \\
\hline Free fatty acid ${ }^{\circ}$ & 31.7 & 29.3 & 28.6 & 24.6 & 7.4 & 12.4 & 14.2 & 31.4 & 24.0 & 5.3 \\
\hline Triacylglycerol & 7.8 & 22.0 & 27.6 & 4.0 & 3.6 & 2.3 & 49.9 & 12.5 & 28.6 & 64.4 \\
\hline Alkyl diacylglycerols & ols 0 & 1.5 & 2.4 & 0 & 3.6 & 0.9 & 4.1 & 0.5 & 1.0 & 5.5 \\
\hline Wax esters & 26.8 & 8.9 & 5.9 & 12.2 & 64.0 & 59.6 & 2.1 & 1.6 & 1.1 & 0 \\
\hline Sterol ester & 0 & 0 & 0 & 0 & 0 & $\operatorname{tr}$ & 0 & 0 & 0 & 0.3 \\
\hline Hydrocarbon & 0.6 & 0.6 & 1.1 & 1.0 & 0.3 & 0.8 & 0.9 & 0.9 & 1.0 & 0.9 \\
\hline
\end{tabular}


amounts of total carotenoid pigments in Mirocaris fortunata were variable, with the lowest levels detected in eggs ( 0.77 to $0.79 \mu \mathrm{g}$ egg carotenoid female $\left.{ }^{-1}\right)$ and the highest in the heavily pigmented small adults $(8.6$ to $9.2 \mu \mathrm{g}$ carotenoid shrimp ${ }^{-1}$; Fig. 1A). The category of small adults with low levels of pigmentation contained only 0.9 to $2.9 \mu \mathrm{g}$ carotenoid shrimp ${ }^{-1}$. Considering their relatively large size, adult shrimp also contained low levels of carotenoid pigment $(0.7$ to $3.1 \mu \mathrm{g}$ carotenoid shrimp ${ }^{-1}$; Fig. 1A).

Given their size, the highly pigmented small adults contained high levels of total lipid $(3.9 \mathrm{mg}$ lipid shrimp ${ }^{-1}$; Fig. 1B), with approximately twice the level of the similar-sized small adult $\left(\mathrm{a}_{1}: 18 \mathrm{~mm}\right)$ with low amounts of pigmentation ( $2.2 \mathrm{mg}$ lipid shrimp $\left.{ }^{-1}\right)$ and approximately $25 \%$ more than the larger small adults $\left(\mathrm{b}_{1}, \mathrm{c}_{1}, \mathrm{~d}_{1}: 22 \mathrm{~mm}\right)$ also with low pigmentation $(2.8 \mathrm{mg}$ lipid shrimp ${ }^{-1}$; Fig. 1B). The highest lipid content of an individual sample was detected in a female shrimp which had eggs attached to its pleopods $(4.0 \mathrm{mg}$ lipid shrimp $^{-1}$, egg lipid not included in this value). The
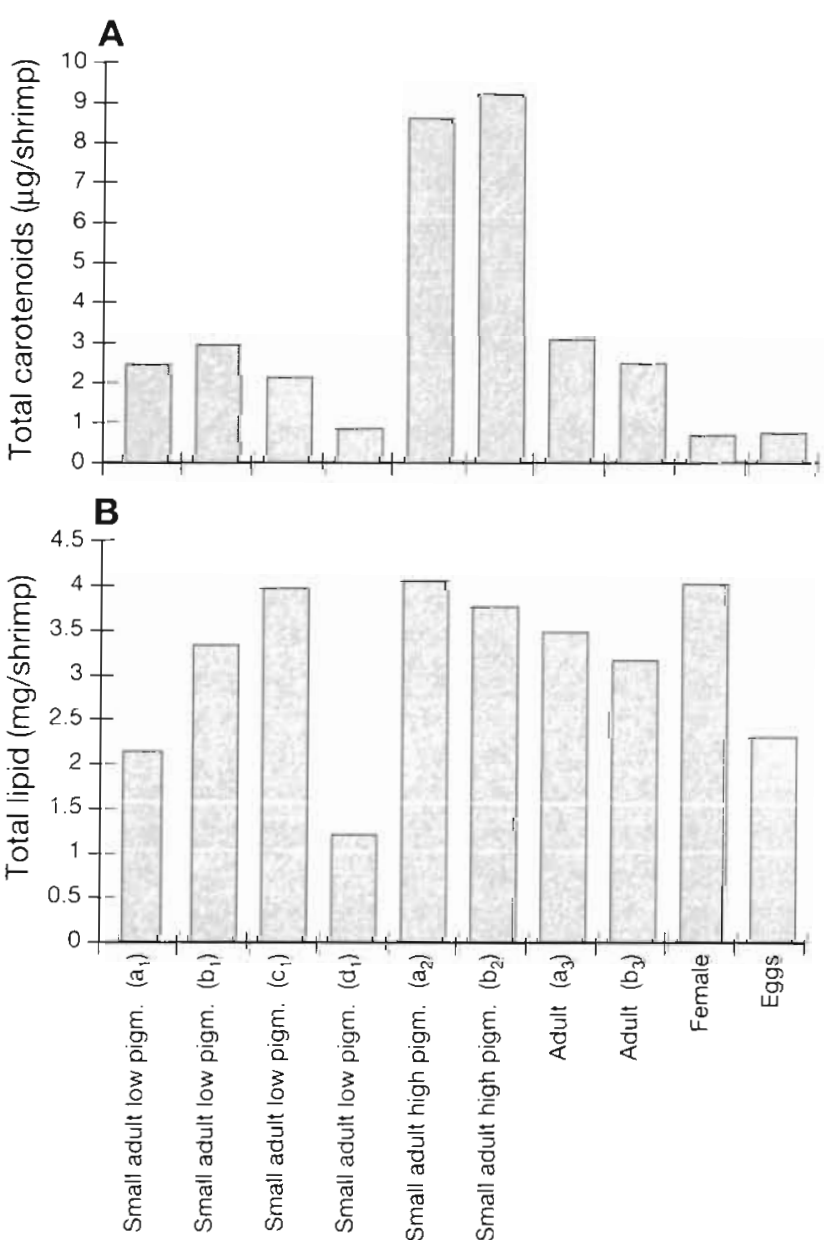

Fig. 1. Mirocaris fortunata. Total carotenoid pigment and total lipid content of various life-history stages. pigm.: pigmentation eggs from this female, which were removed and analysed separately, amounted to $57 \%$ of the female's total lipid pool. A further 3 samples of eggs, for which the corresponding females were not available for analysis, also contained relatively high amounts of lipid (2.2 to $3.5 \mathrm{mg}$ lipid egg batch ${ }^{-1}$ ).

Lipid class analysis showed high levels of free fatty acids in some samples, which suggests lipase hydrolysis of the samples during the unavoidable delay between the collection of the samples at the vent site and transport to the surface $(>6 \mathrm{~h})$. However, in spite of the high levels of free fatty acids, there are some striking differences between the different sex and maturity stages of Mirocaris fortunata. The highly pigmented small adults $\left(a_{2}\right.$ and $b_{2}: 17$ and $19 \mathrm{~mm}$ respectively) contained high proportions of wax esters, which accounted for $62.5 \%$ of total lipid (Table 1 ). The category of small adults $\left(b_{1}, c_{1}, d_{1}: 22 \mathrm{~mm}\right)$ which contained only low levels of carotenoid pigment were comparatively depleted in wax esters but did contain higher proportions of polar lipid and triacylglycerols (Table 1). A further specimen, treated separately on account of its relatively small size, small adult $\left(\mathrm{a}_{1}\right.$ : $18 \mathrm{~mm}$ ), contained intermediate proportions of wax ester and triacylglycerol (26.8 and 7.8\% respectively). The lipid class composition of egg samples was dominated by triacylglycerols, which accounted for up to $75.6 \%$ of total lipid. Wax esters were not detected in the samples of eggs (Table 1$)$. Adults $\left(a_{3}\right)$ and $\left(b_{3}\right)$ were not sexed, but it is apparent that both these specimens contained only very low levels of wax ester and that adult $\left(b_{3}\right)$ contained high proportions of triacylglycerol.

Fatty acid compositions of the different sex and maturity stages of Mirocaris fortunata were markedly different. The highly pigmented small adults contained high levels of polyunsaturated fatty acids $20: 5(\mathrm{n}-3)$ and $22: 6(n-3)$, and also a high level of $18: 1(n-9)$ relative to 18:1(n-7) (Table 2, Fig 2B). By contrast, the small adults which contained only low levels of pigmentation were characterised by much lower proportions of $20: 5(n-3)$ and 22:6(n-3), higher proportions of $16: 1(n-7)$, $18: 1(n-7), 16: 2(n-4), 18: 2(n-4)$ and the non-methylene interrupted diene (NMID) 22:2 $\Delta, 15$, and the presence of 20:2 $\Delta 5,13$ (Table 2, Fig. 2). The small adult $\left(a_{1}\right)$ again appeared to be intermediate between the high and low pigmented small adults, containing relatively high levels of 20:5(n-3) and 22:6(n-3) but also the (n-4) and NMID fatty acids. Egg samples were dominated by saturated and monounsaturated fatty acids, particularly $16: 0,16: 1(n-7), 18: 1(n-9)$ and $18: 1(n-7)$, although the $(n-4)$ and NMID fatty acids were also detected in relatively high abundances (Fig. 2D). However, polyunsaturated fatty acids (PUFA), which are important constituents of cell membranes in marine organisms in 
Table 2. Mirocaris fortunata. Fatty acid composition (wt \%) of various life stages. (Fatty alcohols in parentheses; pigm.: pigmentation; tr: trace quantities $<0.1 \%$ )

\begin{tabular}{|c|c|c|c|c|c|c|c|c|c|c|}
\hline & $\begin{array}{l}\text { Small adult } \\
\text { low pigm. } \\
\left(a_{1}\right)\end{array}$ & $\begin{array}{l}\text { Small adult } \\
\text { low pigm. } \\
\qquad\left(b_{1}\right)\end{array}$ & $\begin{array}{l}\text { Small adult } \\
\text { low pigm. } \\
\left(c_{1}\right)\end{array}$ & $\begin{array}{l}\text { Small adult } \\
\text { low pigm. } \\
\left(\mathrm{d}_{1}\right)\end{array}$ & $\begin{array}{c}\text { Small adult } \\
\text { high pigm. } \\
\qquad\left(\mathrm{a}_{2}\right)\end{array}$ & $\begin{array}{l}\text { Small adult } \\
\text { high pigm } \\
\qquad\left(b_{2}\right)\end{array}$ & $\begin{array}{l}\text { Adult } \\
\left(\mathrm{a}_{3}\right)\end{array}$ & $\begin{array}{l}\text { Adult } \\
\left(\mathrm{b}_{3}\right)\end{array}$ & $\begin{array}{c}\text { Female w } \\
\text { Female }\end{array}$ & $\begin{array}{l}\text { ith eggs } \\
\text { Eggs }\end{array}$ \\
\hline $\begin{array}{l}\text { Total length } \\
(\mathrm{mm})\end{array}$ & 18 & 22 & 22 & 22 & 17 & 19 & 25 & 26 & 25 & \\
\hline \multicolumn{11}{|l|}{ Fatty acid } \\
\hline $14: 0$ & 1.8 & 3.6 & 3.2 & 1.0 & 0.4 & 0.3 & 30 & 2.0 & 3.0 & 3.4 \\
\hline $14: 1$ & 0.8 & 1.0 & 1.9 & 0.3 & 0.2 & 0.2 & 0.8 & 0.9 & 0.8 & 0.9 \\
\hline $15: 0$ & 0.1 & 0.1 & 0.2 & tr & 0 & $\operatorname{tr}$ & 0.1 & 0.2 & 0.2 & 0.1 \\
\hline $16: 0$ & $10.0(49.4)$ & 13.3 & 11.8 & 11.4 & $4.0(48.9)$ & $3.9(47.8)$ & 13.0 & 11.7 & 11.0 & 10.9 \\
\hline $16: 1(n-7)$ & 20.5 & 22.3 & 27.8 & 14.9 & 11.1 & 8.3 & 32.5 & 27.7 & 23.9 & 32.0 \\
\hline $16: 1(n-5)$ & $\mathrm{tr}$ & $\operatorname{tr}$ & $\mathrm{tr}$ & $\operatorname{tr}$ & 0 & 0 & tr & $\operatorname{tr}$ & $\operatorname{tr}$ & $\operatorname{tr}$ \\
\hline $16: 2(n-4)$ & 0.6 & 0.8 & 1.4 & 0.3 & 0.3 & 0.1 & 1.4 & 0.5 & 1.1 & 1.5 \\
\hline $17: 0$ & $\operatorname{tr}$ & $\operatorname{tr}$ & $\operatorname{tr}$ & $\operatorname{tr}$ & $\operatorname{tr}$ & 0 & tr & 0 & 0 & $\operatorname{tr}$ \\
\hline $16: 3(n-3)$ & 0.2 & 0.4 & 0.2 & 0.3 & 0.6 & 0.3 & 0.5 & 0.4 & 0 & 0.5 \\
\hline $16: 4(n-3)$ & 0 & 0 & 0 & 0 & 0 & 0 & 0 & 0 & 0 & 0 \\
\hline $18: 0$ & $2.6(9.9)$ & 2.8 & 2.4 & 3.4 & $1.2(10.3)$ & $1.5(13.1)$ & 1.8 & 2.6 & 3.0 & 2.0 \\
\hline $18: 1(n-9)$ & $6.1(22.8)$ & 6.8 & 5.7 & 10.9 & $15.0(18.6)$ & $14.8(18.2)$ & 9.0 & 7.7 & 10.6 & 11.2 \\
\hline $18: 1(n-7)$ & $16.0(17.9)$ & 22.3 & 17.8 & 17.5 & $6.0(22.2)$ & $6.3(20.9)$ & 20.2 & 18.7 & 20.9 & 19.7 \\
\hline $18: 1(n-5)$ & $\operatorname{tr}$ & $\mathrm{tr}$ & $\mathrm{tr}$ & $\mathrm{tr}$ & 0 & 0 & tr & $\operatorname{tr}$ & $\operatorname{tr}$ & tr \\
\hline $18: 2(n-6)$ & 1.5 & 0.5 & 2.4 & 1.2 & 1.5 & 1.3 & 1.0 & 1.7 & 0.7 & 0.9 \\
\hline $18: 2(n-4)$ & 3.1 & 3.6 & 5.3 & 1.7 & 0.6 & 0.6 & 4.6 & 2.5 & 3.8 & 5.1 \\
\hline $20: 0$ & 0.2 & 0.2 & 0.1 & 0.3 & 0.3 & 0.1 & 0.1 & 0.2 & 0.3 & 0.2 \\
\hline $20: 1(n-9+n-7)$ & 0.7 & 0.3 & 1.1 & 0.4 & 0.4 & 0.4 & 1.2 & 1.3 & 1.6 & 1.4 \\
\hline $20: 2 \Delta 5,13$ & 2.5 & 1.9 & 2.2 & 2.5 & 0 & 0 & 4.2 & 3.6 & 4.9 & 3.7 \\
\hline $20: 4(n-6)$ & 1.2 & 0.8 & 0.9 & 2.3 & 5.5 & 3.2 & 0.5 & 2.1 & 1.3 & 0.4 \\
\hline $20: 4(n-3)$ & 0.3 & 0.2 & 0.1 & 0.1 & 0.6 & 0.7 & 0.1 & 0.2 & 0.1 & 0 \\
\hline $20: 5(n-3)$ & 7.0 & 4.1 & 3.5 & 9.6 & 12.2 & 15.8 & 1.3 & 5.1 & 3.8 & 1.1 \\
\hline $22: 1(n-9)$ & 0.3 & 0.2 & 0.4 & 1.1 & 0 & 0 & 0.2 & 1.1 & 0 & 0.3 \\
\hline $22: 2 \Delta 7,15$ & 1.8 & 2.4 & 2.6 & 3.2 & 0.4 & 0.3 & 2.1 & 3.1 & 2.7 & 1.6 \\
\hline $22: 5(n-6)$ & 0 & 0.2 & 0.2 & 0.5 & 6.5 & 3.5 & 0 & 0.2 & 0 & 0 \\
\hline $22: 5(n-3)$ & 0.6 & 0.3 & 0.2 & 0.2 & 2.4 & 2.0 & 0.1 & 0.7 & 0.3 & 0 \\
\hline $22: 6(n-3)$ & 21.8 & 12.0 & 8.5 & 17.1 & 30.6 & 36.4 & 2.3 & 6.1 & 6.0 & 2.9 \\
\hline $24: 1(\mathrm{n}-9)$ & $\operatorname{tr}$ & $\operatorname{tr}$ & $\operatorname{tr}$ & $\operatorname{tr}$ & $\operatorname{tr}$ & $\operatorname{tr}$ & $\operatorname{tr}$ & $\operatorname{tr}$ & tr & $\operatorname{tr}$ \\
\hline
\end{tabular}

general, comprised only very minor components of egg lipid (Table 2, Fig. 2D).

Fatty alcohols were analysed only in small adult samples where wax esters comprised major components of total lipid. The fatty alcohols profiles were dominated by 16:0 with lesser amounts of 18:0, 18:1(n-9) and 18:1(n-7) (Table 2).

The ${ }^{13} \mathrm{C} /{ }^{12} \mathrm{C}$ stable isotope composition of individual fatty acids in the shrimp samples were very variable, with values ranging from $-12.5 \%$ for $18: 1(n-7)$ in small adult $\left(b_{1}\right)$ to $-33.1 \%$ for the NMID $20: 2 \Delta 5,13$ in small adult $\left(d_{1}\right)$ (Table 3, Fig. 3). Even within single animals, the $\delta^{13} \mathrm{C}$ of fatty acids varied by up to $18.8 \%$ [small adult $\left(\mathrm{b}_{1}\right)$, Table 3]. The stable isotope compositions were least variable in the 2 highly pigmented small adult shrimp and were typically in the range -20 to $-25 \%$ [range of 8.6 and $7.8 \%$ for adults $\left(a_{2}\right)$ and $\left(b_{2}\right)$ respectively].

On the basis of ${ }^{13} \mathrm{C} /{ }^{12} \mathrm{C}$ isotope ratios, low pigmented small adult and adult shrimps appear to fall into 2 categories. In these shrimp the isotope ratios for the
PUFA, 20:2 NMID, 20:4(n-6), 20:5(n-3), 22:2 NMID and $22: 6(n-3)$ are essentially similar and comparatively isotopically light $(-25$ to $-33.1 \%)$. However, the shorter and less unsaturated fatty acids 14:0, 16:0,16:1(n-7), 18:1(n-9), 18:1(n-7) and 18:2(n-4) show a bimodal distribution of isotope compositions (Table 3, Fig. 3). Thus, in small adults $\left(b_{1}\right)$ and $\left(c_{1}\right)$, adult $\left(a_{1}\right)$ and the female shrimp, these fatty acids are comparatively enriched in ${ }^{13} \mathrm{C}(-12.5$ to $-23.6 \%)$, whereas in small adult $\left(d_{1}\right)$ and adult $\left(b_{3}\right)$, these fatty acids are isotopically light $(-21.8$ to $-29.5 \%$ ) It is notable that these latter 2 shrimp, i.e. with ${ }^{13} \mathrm{C}$-depletion in the shorter and less unsaturated fatty acids, also contained low amounts of triacylglycerols in their total lipid (Table 1). The small adult $\left(a_{1}\right)$ again appears to be intermediate and its isotope values for these fatty acids span the range -19.3 to $24.2 \%$. The stable isotope composition of fatty acids in the adult female and corresponding egg were similar, although corresponding fatty acids in the eggs tended, overall, to be isotopically heavier than those in the female (Table 3). 

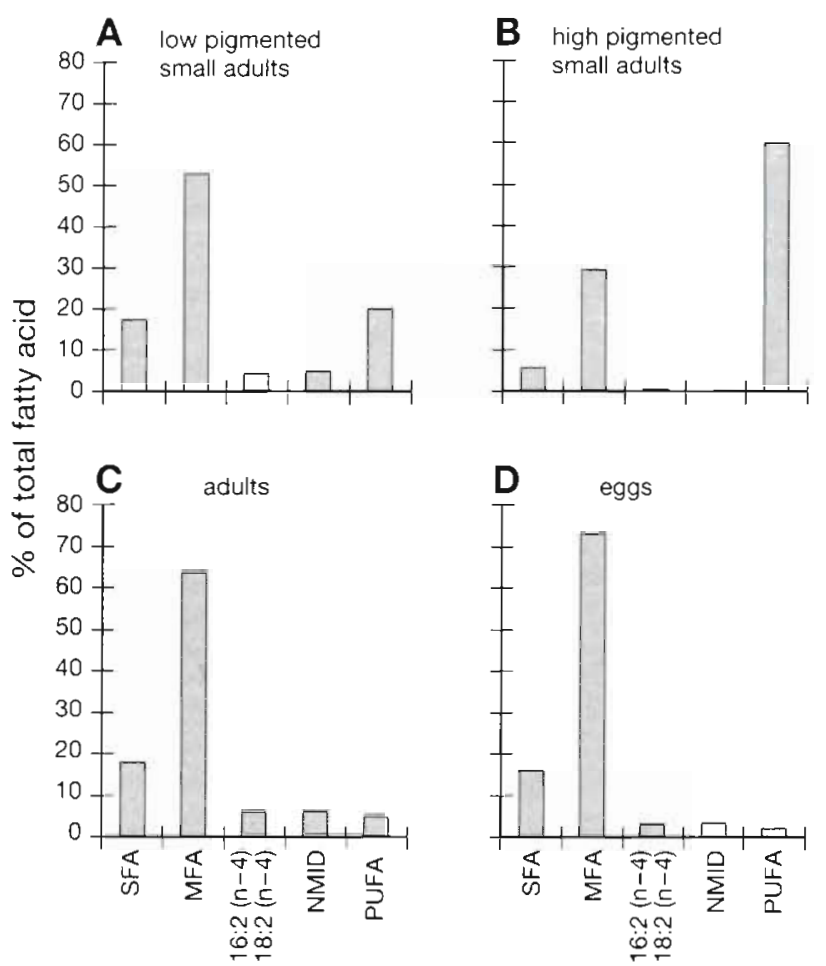

Fig. 2. Mirocaris fortunata. Proportions of different groups of fatty acids from various life history stages of shrimps sampled from the Lucky Strike vent site. SFA: saturated fatty acid; MFA: monounsaturated fatty acid; NMID: non-methylene interrupted dienes; PUFA: polyunsaturated fatty acids, i.e. 3 or more double bonds
For the 3 small adult shrimp where wax esters were a major component of total lipid $\left(a_{1}, a_{2}, b_{2}\right)$, the ${ }^{13} \mathrm{C} /{ }^{12} \mathrm{C}$ stable isotope composition of individual fatty alcohols was less variable than corresponding fatty acids $(-21.0$ to $-26.2 \%)$. The fatty alcohols $16: 0$ and $18: 1(n-9)$ had $\delta^{13} \mathrm{C}$ values approximately 3 to $5 \%$ lower in the low pigmented small adult relative to the highly pigmented shrimp (Table 3).

\section{DISCUSSION}

\section{Nutritional ecology}

The fatty acid composition of adult Mirocaris fortunata is intermediate between that of other species of shrimp sampled from MAR vent sites, i.e. Rimicaris exoculata, which is considered to be bactivorous, and Alvinocaris markensis, a recognised scavenger (Segonzac et al. 1993, Pond et al. 1997a). The fatty acids $16: 2(n-4)$ and $18: 2(n-4)$, thought to be derived from sulphur oxidizing filamentous bacteria found within the TAG (trans Atlantic geotraverse) and Snake Pit vent ecosystems (Pond et al. 1997a), were a relatively minor component of the fatty acid pool of adult $M$. fortunata, and this suggests that these bacteria are not a major nutritional source for this species, either directly or indirectly. In contrast to TAG and Snake Pit, the high temperature fluids associated with the Lucky

Table 3. Mirocaris fortunata. ${ }^{13} \mathrm{C} /{ }^{12} \mathrm{C}$ isotope values of fatty acids and fatty alcohols (in parentheses) from various life stages. (All values corrected for $-41 \%$ methanol and $-27 \%$ acetate derivatization reagents; pigm.. pigmentation; nd: not detectable)

\begin{tabular}{|c|c|c|c|c|c|c|c|c|c|c|}
\hline & $\begin{array}{c}\text { Small adult } \\
\text { low pigm. } \\
\left(a_{1}\right)\end{array}$ & $\begin{array}{l}\text { Small adult } \\
\text { low pigm. } \\
\left(b_{1}\right)\end{array}$ & $\begin{array}{c}\text { Small adult } \\
\text { low pigm. } \\
\left(c_{1}\right)\end{array}$ & $\begin{array}{c}\text { Small adult } \\
\text { low pigm. } \\
\left(d_{1}\right)\end{array}$ & $\begin{array}{c}\text { It Small adult } \\
\text { high pigm. } \\
\left(a_{2}\right)\end{array}$ & $\begin{array}{c}\text { Small adult } \\
\text { high pigm. } \\
\qquad\left(\mathrm{b}_{2}\right)\end{array}$ & $\begin{array}{c}\text { Adult } \\
\left(\mathrm{a}_{3}\right)\end{array}$ & $\begin{array}{l}\text { Adult } \\
\left(\mathrm{b}_{3}\right)\end{array}$ & $\begin{array}{c}\text { Female w } \\
\text { Female }\end{array}$ & $\begin{array}{c}\text { rith eggs } \\
\text { Eggs }\end{array}$ \\
\hline $\begin{array}{l}\text { Total length } \\
(\mathrm{mm})\end{array}$ & 18 & 22 & 22 & 22 & 17 & 19 & 25 & 26 & 25 & \\
\hline \multicolumn{11}{|l|}{ Fatty acid } \\
\hline 14:0 & -19.3 & -15.2 & -16.6 & -25.1 & nd & nd & -13.6 & -21.8 & -15.2 & -16.6 \\
\hline $16: 0$ & $-23.8(-26.2)$ & -15.3 & -22.5 & -26.2 & $-23.6(-21.7)$ & $-20.9(-21.0)$ & -15.0 & -26.1 & -15.0 & -14.9 \\
\hline $16: 1(n-7)$ & -21.6 & -12.6 & -19.9 & -25.8 & -22.5 & -20.8 & -13.9 & -24.8 & -13.3 & -13.0 \\
\hline $16: 2(n-4)$ & nd & nd & -24.9 & nd & nd & nd & -23.1 & nd & -22.7 & -22.3 \\
\hline $18: 0$ & $-26.9(-24.3)$ & -22.5 & -25.5 & -29.8 & $-27.7(-24.7)$ & $-25.1(-23.8)$ & -23.9 & -28.4 & -24.9 & -21.8 \\
\hline $18: 1(n-9)$ & $-22.5(-24.9)$ & -20.5 & -20.1 & -29.5 & $-19.0(-21.4)$ & $-18.2(-20.8)$ & -17.4 & -26.9 & -16.7 & -13.4 \\
\hline $18: 1(n-7)$ & $-24.2(-25.5)$ & -12.5 & -23.6 & -27.9 & $-24.8(-23.7)$ & $-22.6(-22.6)$ & -12.7 & -27.0 & -13.0 & -14.7 \\
\hline $18: 2(n-6)$ & -31.0 & nd & -30.0 & nd & nd & nd & nd & -31.3 & nd & -26.5 \\
\hline $18: 2(n-4)$ & -23.0 & -22.2 & -20.3 & -28.9 & nd & nd & -20.1 & -28.4 & -22.2 & -17.9 \\
\hline $20: 2 \Delta 5,13$ & -31.2 & -25.0 & -31.8 & -33.1 & - & - & -28.0 & -31.4 & -25.5 & -24.3 \\
\hline $20: 4(n-6)$ & -29.6 & nd & nd & nd & -23.1 & -25.3 & nd & nd & -30.3 & nd \\
\hline $20: 5(n-3)$ & -29.8 & -31.3 & -32.6 & -31.8 & -22.6 & -21.4 & -31.8 & -32.0 & -30.3 & nd \\
\hline $22: 2 \Delta 7,15$ & -30.2 & -27.4 & -30.9 & -32.1 & - & - & -28.7 & -31.5 & -26.8 & nd \\
\hline $22: 5(n-6)$ & nd & nd & nd & nd & -23.6 & -26.0 & nd & nd & - & - \\
\hline $22: 6(n-3)$ & -27.0 & -28.7 & -31.7 & -29.2 & -20.2 & -18.3 & nd & -30.5 & -28.8 & nd \\
\hline
\end{tabular}



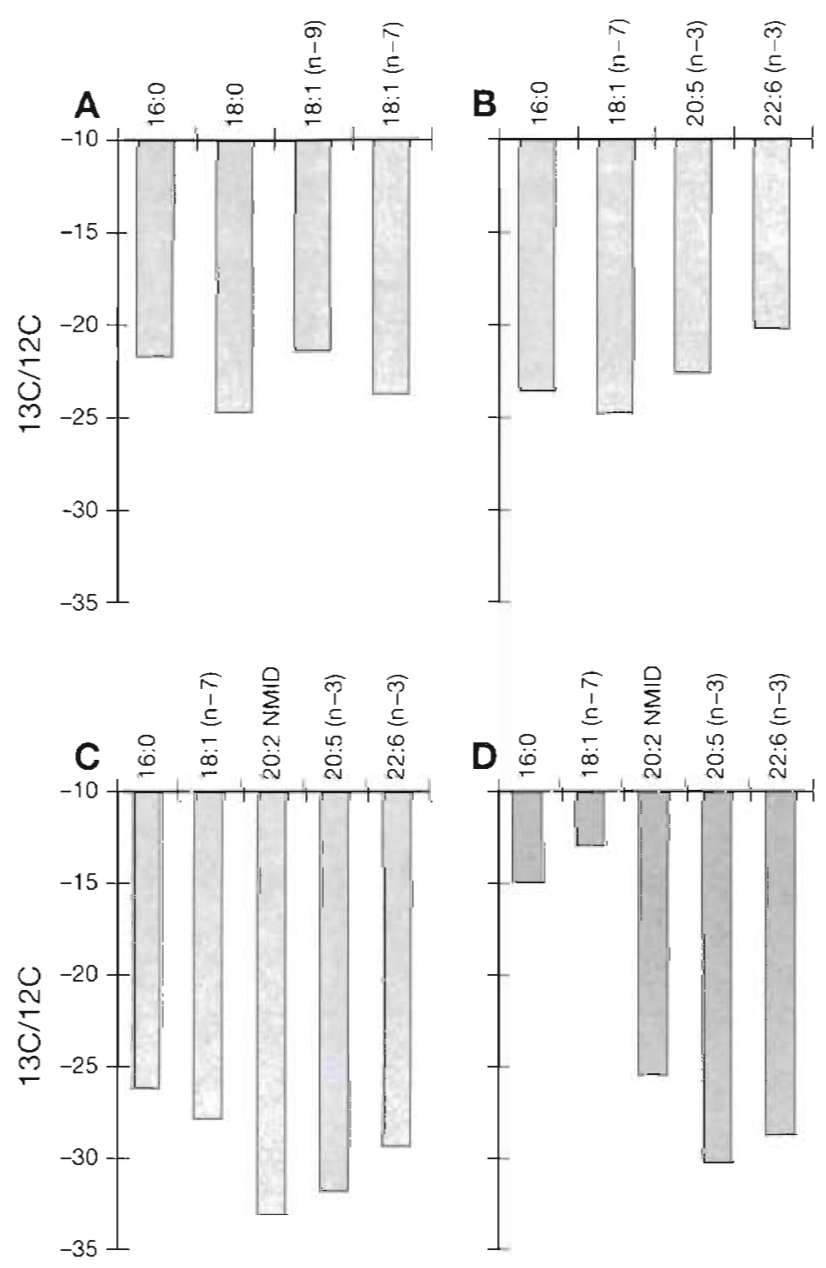

Fig. 3. Mirocaris fortunata. The $\delta^{13} \mathrm{C}$ composition of (A) fatty alcohols from high pigmented small adult $\left(\mathrm{a}_{2}\right)$, and selected fatty acids from (B) high pigmented small adult $\left(\mathrm{a}_{2}\right),(\mathrm{C})$ low pigmented small adult $\left(d_{1}\right)$, and $(D)$ the egg carrying female

Strike system contain low concentrations of sulphide (<3.3 mmol l-1) (Van Dover 1995). This could explain the limited contribution of filamentous sulphur oxidizing bacteria in the diet of $M$. fortunata, as concluded from fatty acid analyses, and may also account for the low abundance of $R$. exoculata at Lucky Strike (Segonzac pers. obs.).

However, although these sulphur oxidizing bacteria containing $16: 2(n-4)$ and $18: 2(n-4)$ fatty acids do not appear to be an important dietary component for Mirocaris fortunata, the high levels of $16: 1(\mathrm{n}-7)$ and 18:1(n-7) fatty acids coupled with relatively high levels of NMIDs [fatty acids which are elaborated from 18:1(n-7)] do indicate a significant component of other bacteria in the diet of this species. The samples of $M$. fortunata analysed in the present investigation were collected from an area extensively colonised by vent mussels (Bathymodiolus sp.). It seems plausible that a non- sulphur oxidizing bacterial food source associated with the mussels and/or mussel-derived material, such as pseudo-faeces and mucus, contributes to the diet of this shrimp. The contribution of 'mussel-derived material' in the nutrition of vent communities has been reported previously. In a study of organisms from the Galapagos Rift hydrothermal vent site, Fisher et al. (1994) found a tight coupling between the stable isotopes composition of the mussel Bathymodiolus thermophilus and the gastropod Phymorhynchus sp., which suggested that a substantial proportion of the gastropod diet was derived from the mussels.

In the present study, this supposition is also supported by ${ }^{13} \mathrm{C} /{ }^{12} \mathrm{C}$ stable isotope analyses of individual fatty acids. Low pigmented small adult and adult shrimp contained a number of comparatively light $\delta^{13} \mathrm{C}$ fatty acids (approx. -27 to $-33 \%$ ), the $\delta^{13} \mathrm{C}$ values which are typical of thiotrophic organisms. It should be noted that $\delta^{13} \mathrm{C}$ values of ca $12 \%$ are also characteristic of thiotrophic bacteria as isotope ratios for these organisms tend to be bimodal (Fisher et al. 1990). MAR vent mussels from Snake Pit (Bathymodiolus puteoserpentis) are known to contain thiotrophic symbionts ( -33.7 to $-34.5 \%$; Cavanaugh et al. 1992). Transmission electron microscopy of these mussels has also indicated the presence of endosymbionts with stacked intracellular membranes similar to those found in methylotrophic mussels from the Pacific sites (De Angelis et al. 1991, Cavanaugh et al. 1992). Enzyme assays of the mussel gill tissue has confirmed the presence of methanol dehydrogenase, an enzyme which is indicative of methylotrophy and the utilisation of $\mathrm{CH}_{4}$ as a carbon source (Cavanaugh et al. 1992). The mussels at Lucky Strike also contained both thiotrophic and methylotrophic endosymbionts (Fiala-Médioni et al. 1996), although the $\delta^{13} \mathrm{C}$ value for total carbon was higher, i.e. $-24.1 \%$ (Van Dover et al. 1996). Fiala-Médioni et al. (1996) suggested that the higher $\delta^{13} \mathrm{C}$ value at Lucky Strike indicated a greater importance of methane in this ecosystem, a supposition which is supported by the relatively high concentrations of methane in the seawater at this site. However, as the $\delta^{13} \mathrm{C}$ of this methane source has not been determined, such an assumption remains speculative.

The PUFA 20:5(n-3) and 22:6(n-3) in the low pigmented small adults and adults were isotopically light $(-27.0$ to $-32.6 \%$, i.e. substantially lighter than in the pigmented shrimp), which suggests that these compounds were synthesised from carbon 'fixed' within the vent ecosystem. Bacteria in general do not synthesise PUFA as they lack the necessary $\mathrm{O}_{2}$-dependent fatty acid desaturases. However, it has been established that a few bacterial strains isolated from fish guts (Yazawa et al. 1988) and some deep-sea bacteria 
can be prolific producers of 20:5(n-3) and 22:6(n-3) (De Long \& Yayanos 1986). Pond et al. (1997a) did not find any evidence to suggest that these (n-3) PUFA were synthesised within the TAG ecosystem; rather the ${ }^{13} \mathrm{C} /{ }^{12} \mathrm{C}$ composition of these fatty acids in the TAG ecosystem was consistent with a photic origin. However, at Lucky Strike, limited synthesis of these fatty acids seems plausible, especially given the similarity of their stable isotope compositions to the NMIDs $20: 2 \Delta 5,13$ and $22: 2 \Delta 7,15$. These NMID fatty acids are characteristic of organisms whose diets are rich in 16:0, 16:1(n-7) and 18:1(n-7) with a relative paucity of PUFA, and thus are certainly synthesised within the vent ecosystem (Ackman \& Hooper 1973. Zhukova 1991, Fullarton et al. 1995, Pond et al. 1997a). However, it is important to appreciate that the shrimp contained only very low levels of $20: 5(n-3)$ and 22:6(n-3), particularly the eggs, which suggests only a limited dietary availability of these compounds for Mirocaris fortunata. Overall, these results are consistent with $M$. fortunata adopting an opportunistic mode of nutrition with bacteria and mussel-derived material featuring in its diet.

\section{Egg lipids}

Mirocaris fortunata broods a moderate number of eggs (max. observed 500; Segonzac unpubl.) comparatively well provisioned with triacylglycerols. Such a strategy is typical of open ocean and deep-sea environments, where predation rates are generally low, but contrasts to the situation in shallow coastal waters, where predation pressure is high, and Crustacea typically produce large numbers of smaller eggs (Pollock \& Melville-Smith 1993). Most notably, the eggs of $M$. fortunata contained very low levels of $20: 5(n-3)$ and 22:6(n-3), nutrients which are generally considered essential for growth and development of higher marine organisms where they serve a fundamental structural role in cell membranes. In particular, the embryonic and larval stages of marine organisms require substantial amounts of these compounds, as these early life-history stages typically exhibit very fast growth and development rates (Sargent et al. 1995, Pond et al. 1996). It has previously been established that the lipidrich larvae of some vent shrimp species adopt a typically bathypelagic lifestyle which is thought to facilitate dispersal of these species (Herring 1996, Pond et al. 1997b). However, the fatty acid composition of the eggs of $M$. fortunata suggests that nutritional factors may also be important in determining the requirement for a pelagic phase in the life-history of vent shrimp. Thus the larvae may be required to swim up into the water column in order to obtain essential nutrients such as PUFA from photically derived material to enable normal growth and development during the zoeal and post larval stages.

\section{Life history strategy}

The difference in lipid compositions between the high and low pigmented small adults is impressive. The lipid composition of the highly pigmented individuals, both in terms of lipid class (wax esters) and fatty acid profiles [18:1(n-9)/18:1(n-7) ratio, 20:5(n-3) and $22: 6(n-3)]$ is similar to that of the planktonic larvae of vent shrimp (Pond et al. 1997b). This evidence alone strongly suggests that these pigmented small adults had also spent a considerable period of their early life stages leading a planktonic existence and had recently metamorphosed before settling at the Lucky Strike vent site. This supposition is convincingly supported by GC-IRMS analysis of the fatty acids and fatty alcohols. The ${ }^{13} \mathrm{C} /{ }^{12} \mathrm{C}$ isotopic composition of carbon fixed within the surface layers of the marine environment typically range from -17 to $-27 \%$ (Goericke et al. 1994). Thus, values of -18.5 to $-27.7 \%$ for the fatty acids and fatty alcohols in the high pigmented small adults is entirely consistent with a photosynthetic carbon source for these compounds. The difference in lipid composition between the high and low pigmented shrimps could suggest that these shrimp are different species, although genetic information suggests that this is not the case (Dixon unpubl.).

The $\delta^{13} \mathrm{C}$ isotope composition of fatty acids from low pigmented small adults and adults were much more variable $(-12.5$ to $-33.1 \%)$, particularly data for the fatty acids $14: 0,16: 0,16: 1(n-7) 18: 1(n-9)$ and 18:1(n-7), which exhibited a bimodal distribution. Bimodal distributions in the stable isotope compositions for the total carbon content of hydrothermal vent organisms have been reported previously and primarily attributed to differing nutritional sources of isotopically distinct microrganisms (Fisher et al. 1994, Van Dover \& Fry 1994). Although the samples of Mirocaris fortunata from Lucky Strike were collected from the same locality, it is plausible that microscale variability in the food environment of the shrimp accounts for this finding. This would imply that the shrimp are either territorial and hence are restricted to a particular microhabitat or that different shrimp have different feeding preferences. However, it is also possible that the reproductive condition of the shrimp accounts for some of the variability in $\delta^{13} \mathrm{C}$ values observed in the fatty acids. This study has established that adult female shrimp and their eggs are rich in triacylglycerols, compounds which predominantly comprise saturated and monounsaturated fatty acids. In the female shrimp and eggs 
these fatty acids are isotopically heavy which may reflect a more active metabolism/synthesis of these compounds during gonadogenesis. Unfortunately the shrimp were not sexed, so it is not possible to tell if shrimp with similar lipid profiles were females (i.e. high levels of triacylglycerols and isotopically heavy saturated and monounsaturated fatty acids) such as small adults $\left(b_{1}\right)$ and $\left(c_{1}\right)$ and adult $\left(a_{3}\right)$. Clearly more samples are required to establish if this is correct.

The lipid composition of the small adults with only low levels of pigmentation could be explained either by these animals adopting a planktonic phase for a short period of time before encountering a suitable vent site, or having fed and developed in close proximity to the vent environment itself. The capacity for some marine organisms (protochordates) to produce larvae with different behaviours, i.e. one which develops in the vicinity of the vent site, whilst another adopts a planktotrophic lifestyle and delays metamorphosis to facilitate more widespread dispersal, is established in the literature (Goldschmidt 1933, Gibbs \& Wickstead 1996). Thus Mirocaris fortunata could potentially adopt a strategy of hedge betting, a necessary strategy given the unpredictable life-span and geographically dispersed nature of the vent sites, and a strategy which is possibly a key factor in the long-term survival of these organisms. However, a further possibility which could account for the low pigment content, the absence of wax esters and low levels of PUFA in some small adults, should not be overlooked. If these shrimp had returned to the vent site at a much earlier date than when sampled, they could subsequently have catabolised any lipids accumulated during a planktotrophic phase. As yet no information is available on the growth rates of $M$. fortunata, which means that no firm conclusions can be drawn.

Assuming that some larval shrimp do feed and develop at the vent site, then what are the nutritional implications for this strategy? Such a strategy may only be possible during particular seasons, i.e. immediately post-spring bloom and in years when the flux of material derived from the surface-layers is adequate. There is some evidence indicating that surface-layer-derived material reaches the MAR vent sites (Dixon et al. 1995), although the biochemical composition of this material has not been established. Given that the Lucky Strike vent site is only 1600 to $1700 \mathrm{~m}$ deep, it is plausible that, in some circumstances, phytoplanktonic material of sufficient nutritional quality reaches the vent ecosystem and allows successful reproduction and development of shrimp larvae. Caridean shrimp from shallow water environments are known to carry eggs for protracted periods of time, with the eggs hatching when environmental conditions are suitable. Indeed, in some marine Crustacea which brood eggs, increased maternal food availability results in the production of 'hatching factors' which induce the synchronous hatching of eggs (Holland et al. 1985). These 'hatching factors' are trihydroxylated fatty acids, derived from dietary 20:5(n-3) (Hill et al. 1993). This is a potential mechanism whereby Mirocaris fortunata could synchronise the hatching of its eggs with the occurrence of a favourable nutritional environment.

Although the results presented here provide valuable insights into the life-history strategy of Mirocaris fortunata, we suggest that caution should be exercised when extrapolating this information to other vent shrimp species. $M$. fortunata differs fundamentally from other species of hydrothermal vent shrimp in that it only attains a comparatively small size at maturity. Moreover, given the relatively low number of these shrimp collected so far, a high proportion of females has been found carrying eggs, which is in marked contrast to species such as Rimicaris exoculata. Finally, no larval specimens of $M$. fortunata have been identified so far from the plankton (Dixon unpubl.). Nevertheless, the results presented here do suggest that the larvae of this species are capable of adopting a bathypelagic lifestyle.

Acknowledgements. D.W.P. was funded by a Natural Environment Research Council (NERC) PRIME (grant GST/02/1075). This work was also supported by research grants to D.R.D. from the NERC (BRIDGE: GST/02/143) and the European Union (MAST3, AMORES: PL950040). We thank D. Desbruyeres (IFREMER, Brest), chief scientist on the DIVA 2 cruise, for providing the shrimps. The animal identifications were confirmed by Michele de Saint Laurent (Museum of Paris). We also thank C. Taylor for GC-IRMS analysis and $J$. Dick for GC-MS. This is PRIME contribution number 48 .

\section{LITERATURE CITED}

Abrajano TA Jr, Murphy DE, Fang J, Comet P, Brooks JM $(1994){ }^{13} \mathrm{C} /{ }^{12} \mathrm{C}$ ratios of individual fatty acids of marine mytilids with and without bacterial symbionts. Org Geochem 21:611-617

Ackman RG. Hooper SN (1973) Non-methylene interrupted fatty acids in lipids of shallow-water marine invertebrates: a comparison of two molluscs (Littorina littorea and Lunatia triseriata) with the sand shrimp (Crangon septemspinous). Comp Biochem Physiol B 46:153-165

Cavanaugh CM, Wirsen CO, Jannasch HW (1992) Evidence for methylotrophic symbionts in a hydrothermal vent mussel (Bivalvia: Mytilidae) from the mid-Atlantic ridge. Appl Environ Microbiol 58:3799-3803

Christie WW (1982) Lipid analyses, 2nd edn. Pergamon Press, Oxford

De Angelis MA, Reysenbach AL, Baross J (1991) Surfaces of hydrothermal vent invertebrates: sites of elevated microbial $\mathrm{CH}_{4}$ oxidation activity. Limnol Oceanogr 36: 570-577

De Long EF, Yayanos AA. (1986) Biochemical function and ecological significance of novel bacterial lipids in deepsea prokaryotes. Appl Environ Microbiol 51:730-737 
Dixon DR, Jollivet DASB, Dixon LRJ, Nott JA, Holland PWH (1995) The molecular identification of early lifehistory stages of hydrothermal vent organisms. In: Parson LM, Walker CL, Dixon DR (eds) Hydrothermal vents and processes. The Geological Society, London, p $343-350$

Eakin PA, Fallick AE, Gerc J (1992) Some instrumental effects in the determination of stable carbon isotope ratios by gas chromatography-isotope ratio mass spectrometry. Chem Geol 101:71-79

Farquhar JW (1962) Identification and gas-liquid chromatographic behaviour of plasmalogen aldehydes and their acetal, alcohol and acetylated alcohol derivatives. J Lipid Res 3:21-30

Fiala-Médioni A, Cavanaugh C, Dando P, Van Dover C (1996) Symbiotic mussels from the mid-Atlantic ridge: adaptations to trophic resources. J Conference Abstr 1:788

Fisher CR (1990) Chemoautotrophic and methanotrophic symbioses in marine invertebrates. Rev Aquat Sci 2. $399-436$

Fisher CR, Childress JJ, Macko SA, Brooks JM (1994) Nutritional interactions in Galapagos Rift hydrothermal vent communities: inferences from stable carbon isotope analyses. Mar Ecol Prog Ser 103:45-55

Fisher CR, Kennicutt MC. Brooks JM (1990) Stable carbon isotope evidence for carbon limitation in hydrothermal vent vestimeniferans. Science 247:1094-1096

Folch J, Lees N, Sloan-Stanley GH (1957) A simple method for the isolation and purification of total lipid. $\mathrm{J}$ Biol Chem 226:497-509

Fullarton JG, Dando PR, Sargent JR, Southward AJ, Southward EC (1995) Fatty acids of hydrothermal vent Ridgeia piscesae and inshore bivalves containing symbiotic bacteria. J Mar Biol Assoc UK 75:455-468

Gebruk AV, Pimenov NV, Savvichev AS (1993) Feeding specialisation of bresiliid shrimps in the TAG site hydrothermal community. Mar Ecol Prog Ser 98:247-253

Gibbs PE, Wickstead JH (1996) The myotome formula of the lancet Epigonichthys lacayanum (Acrania): can variations be related to larval dispersion patterns? J Nat Hist 30: $615-627$

Goericke R, Montoya JP, Fry B (1994) Physiology of isotopic fractionation in algae and cyanobacteria. In: Lajtha $\mathrm{K}$, Michener RH (eds) Stable isotopes in marine ecology and environmental science. Blackwell Scientific Publications, Oxford, p 187-221

Goldschmidt R (1933) A note on amphioxides from Bermuda based on Dr W Beebe's collections. Biol Bull (Woods Hole) $64: 321-325$

Henderson RJ, Bell MV, Park MT, Sargent JR, Falcon J (1994) Lipid composition of the pineal from rainbow trout (Oncorhynchus mykiss). Lipids 20:311-317

Herring PJ (1996) Travelling shrimp. BRIDGE Newsl 11:6-8

Hill EM, Holland DL, East J (1993) Egg hatching activity of trihydroxylated eicosanoids in the barnacle Balanus balanoides. Biochem Biophys Acta 1157:297-303

Holland DL, East J, Gibson KH. Clayton E, Oldfield A (1985) Identification of the hatching factor of the barnacle Balanus balanoides as a novel eicosanoid 10,11, 12-trihydroxy-581417-eicosatetraenoic acid. Prostaglandins 29 . $1021-1029$

Klinkhammer GP, Chin CS, Wilson C, German CR (1995) Venting of the mid-Atlantic ridge at $37^{\circ} \mathrm{N} 17^{\prime} \mathrm{N}$ : the Lucky Strike hydrothermal site. In: Parson LM, Walker CL, Dixon DR (eds) Hydrothermal vents and processes. The Geological Society, London, p 87-96

Martin JW, Christiansen JC (1995) A new species of the shrmp genus Chorocaris Martin and Hessler, 1990 (Crustacea, Decapoda, Bresilidae) from the hydrothermal vent fields along the mid-Atlantic ridge. Proc Biol Soc Wash 108:220-227

Nichols PD, Guckert JB, White DC (1986) Determination of monounsaturated fatty acid double-bond position and geometry for microbial monocultures and complex consortia by capillary GC-MS of their dimethyl sulphide adducts. J Microbial Methods 5:49-55

Nilsson R, Liljenberg C (1991) The determination of double bond positions in polyunsaturated fatty acids-gas chromatography/mass spectrometry of the diethylamide derivative. Phytochem Anal 2:253-259

Olsen RE, Henderson RJ (1989) The rapid analysis of neutral and polar marine lipids using double development HPTLC and scanning densitometry. J Exp Mar Biol Ecol 129: 189-197

Pollock DE, Melville-Smith R (1993) Decapod life histories and reproductive dynamics in relation to oceanography off southern Africa. S Afr J Mar Sci 13:205-212

Pond DW, Dixon DR, Bell MV, Fallick AE, Sargent JR (1997a) Occurrence of $16: 2(n-4)$ and $18: 2(n-4)$ fatty acids in the lipids of the hydrothermal vent shrimps Rimicaris exoculata and Alvinocaris markensis: nutritional and trophic implications. Mar Ecol Prog Ser 156:167-174

Pond DW, Dixon DR, Sargent JR (1997b) Wax-ester reserves facilitate dispersal of hydrothermal vent shrimps. Mar Ecol Prog Ser 146:289-290

Pond DW, Harris RP, Head RN, Harbour D (1996) Environmental and nutritional factors determining the seasonal variability in the fecundity and egg viability of Calanus helgolandicus in coastal waters off Plymouth, UK. Mar Ecol Prog Ser 143:45-63

Rieley G (1994) Derivatization of organic compounds prior to gas chromatographic-combustion-isotope ratio mass spectrometric analysis: identification of isotope fractionation processes. Analyst 119:915-919

Rieley G, Van Dover CL, Hedrick DB, White DC, Eglinton G (1995) Lipid characteristics of hydrothermal vent organisms from 9"N East Pacific Rise. In: Parson LM, Walker CL, Dixon DR \{eds\} Hydrothermal vents and processes. The Geological Society, London, p 329-342

Sargent JR, Bell MV, Bell JG, Henderson RJ, Tocher DR (1995) Origins and functions of $\mathrm{n}-3$ polyunsaturated fatty acids in manine organisms. In: Ceve $G$, Paltauf $F$ (eds) Phospholipids characterization, metabolism and novel biologiocal applications. Am Oil Soc Press, Champaign, IL, p 248-259

Segonzac M, de Saint-Laurent M, Casanova B (1993) L'énigme du comportement trophique des crevettes Alvinocarididae des sites hydrothermaux de la dorsale médio-atlantique. Cah Biol Mar 34:535-571

Sofer Z (1980) Preparation of carbon dioxide for stable isotope analysis of petroleum fractions. Anal Chem 52: $1389-1391$

Van Dover CL (1995) Ecology of Mid-Atlantic Ridge hydrothermal vents. In: Parson LM, Walker $\mathrm{CL}$, Dixon DR (eds) Hydrothermal vents and processes. The Geological Society, London, p 257-294

Van Dover $C L$, Desbruyéres $D$, Segonzac $M$, Comtet $T$, Saldanha L, Fiala-Médioni A, Langmuir C (1996) Biology of the Lucky Strike hydrothermal field. Deep Sea Res 43: $1509-1529$

Van Dover CL, Fry B (1994) Microorganisms as food resources at deep-sea hydrothermal vents. Limnol Oceanogr 39: $51-57$

Van Dover CL, Fry B, Grassle JF, Humphris S, Rona PA (1988) 
Feeding biology of the shrimp Rimicaris exoculata at hydrothermal vents on the Mid-Atlantic Ridge. Mar Biol 98:209-216

Vereshchaka AL (1996) A new genus and species of caridean shrimp (Crustacea: Decapoda: Alvinocarididae) from North Atlantic hydrothermal vents. J Mar Biol Assoc UK 76:951-961

Vereshchaka AL (1997) A new family for a deep-sea caridean shrimp from North Atlantic hydrothermal vents. J Mar Biol Assoc UK 77:425-438

Editorial responsibility: Otto Kinne, Oldendorf/Luhe, Germany
Williams AB, Rona PA (1986) Two new caridean shrimps (Bresiliidae) from a hydrothermal field on the mud-Atlantic ridge. J Crustac Biol 6:446-462

Yazawa K, Araki K, Watanabe K, Ishikawa C, Inoue A, Kondo K, Watabe S, Hashimota K (1988) Eicosapentaenoic acid productivity of the bacteria isolated from fish intestines Nippon Suisan Gakkaishi 54:1835-1838

Zhukova NV (1991) The pathway of the biosynthesis of nonmethylene-interrupted dienoic fatty acids in molluscs Comp Biochem Physiol B 100:801-804

Submitted: May 26, 1997; Accepted: August 8, 1997 Proofs received from author(s): October 1, 1997 